\title{
A DESCRIPTIVE STUDY TO ASSESS THE KNOWLEDGE REGARDING MENSTRUAL BLOOD BANKING AMONG NURSING STUDENTS AT JODHPUR
}

\author{
Geeta Dhaka \\ M. Sc. Nursing (Obs \& Gyn), Govt. College of Nursing, Jodhpur, Rajasthan
}

Article DOI: https://doi.org/10.36713/epra8574

DOI No: $10.36713 /$ epra8574

\begin{abstract}
Introduction: Menstruation is a periodic cycle which occurs after every 28-30 days in every healthy woman after menarche till menopause. In recent years, this blood is considered as best out of waste as pluripotent stem cells can be collected from it. In addition to this, it could be saved for future benefits. In this study, an attempt has been made to rule out nursing student's cognizance regarding menstrual blood banking.

Aim of the study: To assess the knowledge regarding menstrual blood banking among nursing students at Jodhpur.

Material and Method: A descriptive study was carried out on 180 nursing students of Government Nursing College, Jodhpur. Non-probability purposive sampling method was used to select samples. Study was conducted from $17^{\text {th }}$ September to $17^{\text {th }}$ October'2020 using structured knowledge questionnaire. Moreover, study was analysed by using descriptive and inferential statistics.

Result: The findings of the study reveals that majority (58.03\%) of the nursing students had moderate knowledge regarding menstrual blood banking. Furthermore, the study illustrated a significant association between level of knowledge and selected socio- demographic variables.

Conclusion: It can be reiterated that nursing students have an average knowledge regarding menstrual blood banking.

KEY WORDS: Knowledge, menstrual blood banking, menstruation.
\end{abstract}

\section{INTRODUCTION}

Menstruation is the visible manifestation of cyclic and periodic physiologic uterine bleeding as a result of shedding of the endometrial. The uterus experiences change in endometrial thickening, proliferation of the vascular system, secretions from the glands which happen in preparation for receiving a fertilized ovum. However, if the women fail to conceive, functionalize endometrial is shed off which is then visibly known as menstruation. 1

The stem cells in menstrual blood possess extreme proliferative- replicating trait, they can be replicated every 24-36 hours. It is imperative, to record that menstrual stem cells contain embryonic stem cell markers, providing them the noticeable calibre to morph into numerous different healthy cell types. The uncommon characteristic of these cells illustrates the thrilling possibilities, they render in future therapeutic interventions.2,3

Stem cells are vital source of cells that are capable of renewing over long periods of time through cell division of at least one daughter cell coined long term self-renewal. As cells are dividing the new stem cells can remain undifferentiated or become a specific cell type. The cells can become progenitors, a precursor or fully committed cells. Throughout the human body cells are being replenished to replace dying cells or regenerate damaged tissue. Under certain physiological conditions some unspecialized cells may remain 
dormant until the cells are required. If these pluripotent cells are injected into an animal subject, then it can reveal the production of teratomas. On the contrary, adult stem cells have a controlled demeanour and they are multipotent as compared to the embryonic stem cell's pluripotent capacity. 2

The sample collection process of menstrual blood is pretty simple, convenient and non-invasive; like a tampon, a silicone cup is inserted into the vagina on the day of the heaviest flow. The cup is required to be placed inside the vagina for at least three hours so as to collect approximately $20 \mathrm{ml}$ of blood. This is then poured in the collection kit and is sent back to the menstrual blood bank laboratory, where it is processed, frozen and stored for future use. 4

The concept of menstrual blood stem cells banking was initiated in the year 2007 by an American company Cryo cell, and in India it was embarked by life cell international on march 8, 2011 by film actress Lisa Ray, who won the battle with cancer and recovered from deadly disease. The cost of private banking varies depending on the bank, but in general, it ranges from annual storage fees of around 1,500 per year. 5

A plethora of triumphant research studies have depicted that, the use of the stem cells obtained from the endometrial blood for the purpose of treatments of different lethal diseases. The recent innovative discovery of the menstrual blood contains stem cells that are proliferative and are capable of differentiating into different types of cells including cardiac cells, neural cells and into almost 9 types of tissues including heart, liver and lung, has opened a new field for therapeutic treatment. 4,6

The researcher is interested in this topic as many women believe that menstruation is unwanted and unsanitary waste, to bring change in this believe and create insight regarding cutting edge utilisation of menstrual blood. The researcher intended to assess knowledge about menstrual blood banking among nursing students foremost.

\section{OBJECTIVES OF THE STUDY}

- To assess the knowledge regarding Menstrual Blood Banking among nursing students.

- To assess the association between the level of knowledge with selected demographic variables.

\section{HYPOTHESIS OF THE STUDY}

- H0: There will be no significant association between knowledge regarding menstrual blood banking with selected sociodemographic variables at the level of 0.05 .
- H1: There will be significant association between selected socio demographic variables of nursing students and knowledge score on menstrual blood banking.

\section{OPERATIONAL DEFINITIONS}

- ASSESS: In this study, it refers to a critical analysis of systematic and organized collection of objectives data which are helpful to identify and define the level of knowledge regarding menstrual blood banking.

- KNOWLEDGE: In this study, it refers to the correct response of students about information regarding menstrual blood banking in terms of scores through questionnaire.

- MENSTRUAL BLOOD BANKING: Menstrual blood banking is a process for collection of menstrual blood by using tampon or a silicone cup and is inserted in the vagina on the day of heaviest flow. The cup needs to be placed inside the vagina for at least three hours so as to collect approximately 20 milliliters of blood.In this study, menstrual blood banking refers to knowledge regarding menstrual blood banking among nursing students.

- NURSING STUDENTS: In this study, nursing students refers to students of B.sc Nursing $3^{\text {th }} \& 4^{\text {th }}$ year, PBB.sc Nursing, M.Sc. Nursing of selected nursing colleges of Jodhpur.

\section{ASSUMPTION}

- Students may have some knowledge regarding Menstrual Blood Banking.

- The knowledge regarding Menstrual Blood Banking may vary with the selected demographic variables among nursing students at Jodhpur.

\section{CRITERIA FOR SELECTION OF SAMPLE Inclusion criteria}

- Students who are available during the period of data collection

- Students those are willing to participate in the study.

\section{Exclusion criteria}

- Students of B.Sc. nursing 1st and 2nd year.

- Students who are sick to attained the study.

\section{RESEARCH METHODOLOGY \\ - RESEARCH APPROACH}

Quantitative research approach is taken in the current study. 


\section{EPRA International Journal of Research and Development (IJRD)}

\section{- RESEARCH DESIGN}

Descriptive survey design is adopted for the study.

\section{RESEARCH VARIABLE}

- Research variable: Research variable can be defined as quality, attributes, properties or characteristics which are observed or measured in a natural setting without manipulating and establishing cause and effect and relationship. (Sharma Suresh k. 2011). In this study, research variable refers to knowledge regarding menstrual blood banking among nursing students.

- Demographic variable: In this study, variable refers to the age, gender, class, years of clinical experience, marital status, residential place in Jodhpur.

\section{POPULATION}

Population is the entire aggregation of cases that met a designed set of criteria (Polite and Hungler, 1999). In the present study, the population consisted of nursing students of BSC Nursing III \& IV year, PBBBSC (N) Pre \& Final year, MSC (N) Pre \& Final year students of Govt College of Nursing, Jodhpur.

SAMPLING SIZE Sample size is calculated at 95\% confidence interval and $10 \%$ relative allowable error using the formula for sample size for estimation of a single sample proportion- $\mathbf{N}=$ $\left(\mathbf{Z}_{1-\mathrm{a} / 2}\right)^{2} \mathbf{P}(\mathbf{1}-\mathbf{P}) \mathbf{E}^{2}$

Where,

$\mathbf{Z}_{\mathbf{1 - \mathbf { a } / \mathbf { 2 }}}=$ Standard normal deviate for $95 \%$ confidence interval (taken as 1.96)

$\mathbf{P}=$ Expected proportion of idiopathic nursing student's knowledge regarding menstrual blood banking (taken as $7.1 \%$ as reported by Alyse Reichheld et al)
$\mathbf{E}=$ Relative allowable error (taken as $10 \%$ of P) The sample for the study comprised of 180 Nursing students who met the criteria of sample selection.

SAMPLING TECHNIQUE: In the present study non- probability, purposive sampling technique was used to select the samples.

RELIABILITY OF THE TOOL The tool was tested for reliability on 20 respondents i.e. Nursing students of RGM Nursing College, Jodhpur under pilot study.

For self-structured questionnaire via Google forms the reliability was calculated by using Karl Pearson's correlation coefficient method. The reliability coefficient of self-structured knowledge questionnaires was 0.810 .

\section{MAJOR FINDINGS OF THE STUDY}

Table 1 Depicts that the overall mean percentage of knowledge score was $67.57 \%$ with the standard deviation of 8.43 .

Table 2 Shows that the $(58.3 \%)$ of nursing students had average knowledge, whose scores ranged between $16-24,17.8 \%$ had good level of knowledge whose scores ranged between $25-33$ and $23.9 \%$ of nursing students had poor level of knowledge scores ranged between $0-15$ regarding the Menstrual Blood Banking.

Table 3 Illustrates the association between the knowledge level and some selected variable such as age, gender, education level, religion, marital status, income, previous information about menstrual blood banking where class and heard about MBB were found to be significant at the level of $p<0.05$ except the variable i.e. age, gender, clinical experience, marital status and residential were not statistically significant.

Table 1

Mean, SD and mean percentage of the nursing student knowledge scores regarding menstrual blood banking according to aspects

\begin{tabular}{|c|c|c|c|c|}
\hline & & \multicolumn{3}{|c|}{$(\mathbf{N}=180)$} \\
\hline Area of knowledge & $\begin{array}{c}\text { Maximum } \\
\text { score }\end{array}$ & Mean score & SD & Mean \% \\
\hline Introduction Of MBB & 11 & 3.48 & 1.07 & 70.10 \\
\hline Purposes & 3 & 2.11 & 1.86 & 67.92 \\
\hline Characteristics & 3 & 2.01 & 0.74 & 54.83 \\
\hline Procedure & 7 & 2.35 & 1.87 & 55.00 \\
\hline Storage & 4 & 1.63 & 0.55 & 47.67 \\
\hline Advantages & 4 & 3.28 & 1.53 & 69.33 \\
\hline Cost & 1 & 1.90 & 0.81 & 85.03 \\
\hline Total & 33 & 16.76 & 8.43 & $67.57 \%$ \\
\hline
\end{tabular}




\section{EPRA International Journal of Research and Development (IJRD)}

Volume: 6 | Issue: 9 | September 2021

- Peer Reviewed Journal

Table 2

Level of knowledge regarding menstrual blood banking $\quad \mathrm{N}=180$

\begin{tabular}{|c|c|c|c|}
\hline Level of Knowledge & Range of scores & Frequency & Percentage \\
\hline Poor & $0-15$ & 43 & $23.9 \%$ \\
\hline Average & $16-24$ & 105 & $58.3 \%$ \\
\hline Good & $25-33$ & 32 & $17.8 \%$ \\
\hline
\end{tabular}

Table 3

Frequency and percentage distribution of demographic variables among Nursing student $N=180$

\begin{tabular}{|c|c|c|c|c|c|c|c|c|c|}
\hline \multicolumn{10}{|c|}{ KNOWLEDGE SCORE } \\
\hline \multirow{2}{*}{$\begin{array}{c}\text { S. } \\
\text { No. }\end{array}$} & \multirow{2}{*}{ Sample } & \multirow{2}{*}{ Frequency } & \multirow{2}{*}{ Poor } & \multirow{2}{*}{ Average } & \multirow{2}{*}{ Good } & \multirow{2}{*}{$\begin{array}{c}\text { Chi sq } \\
\left(x^{2}\right)\end{array}$} & \multirow{2}{*}{ Df } & \multicolumn{2}{|c|}{ Table value } \\
\hline & & & & & & & & 0.01 & 0.05 \\
\hline \multirow{5}{*}{1} & \multicolumn{5}{|l|}{ Age (in years) } & \multirow{5}{*}{1.489} & \multirow{5}{*}{6} & \multirow{5}{*}{16.81} & \multirow{5}{*}{12.591} \\
\hline & $20-25$ & 131 & 42 & 79 & 25 & & & & \\
\hline & $26-30$ & 30 & 4 & 20 & 3 & & & & \\
\hline & $31-35$ & 11 & 1 & 5 & 2 & & & & \\
\hline & $>35$ & 8 & 2 & 5 & 1 & & & & \\
\hline \multirow{3}{*}{2} & Gender & & & & & \multirow{3}{*}{7.760} & \multirow{3}{*}{4} & \multirow{3}{*}{13.28} & \multirow{3}{*}{9.487} \\
\hline & Male & 65 & 20 & 74 & 14 & & & & \\
\hline & Female & 115 & 23 & 32 & 15 & & & & \\
\hline \multirow{3}{*}{3} & Residential ar & & & & & \multirow{3}{*}{0.896} & \multirow{3}{*}{2} & \multirow{3}{*}{9.21} & \multirow{3}{*}{5.99} \\
\hline & Urban & 72 & 23 & 65 & 19 & & & & \\
\hline & Rural & 108 & 20 & 40 & 13 & & & & \\
\hline \multirow{3}{*}{4} & Marital status & & & & & \multirow{3}{*}{5.426} & \multirow{3}{*}{2} & \multirow{3}{*}{9.21} & \\
\hline & Married & 40 & 15 & 23 & 04 & & & & 3.991 \\
\hline & Unmarried & 140 & 28 & 82 & 28 & & & & \\
\hline & Class & & & & & & & & \\
\hline 5 & B.Sc. N & 126 & 27 & 73 & 25 & 1269 & 4 & 1328 & 9.487 \\
\hline $\mathbf{5}$ & P.B.B.Sc. N & 24 & 12 & 14 & 0 & 12.69 & 4 & 13.28 & \\
\hline & M.Sc. N & 31 & 4 & 18 & 7 & & & & \\
\hline & Nursing experi & & & & & & & & \\
\hline & No experience & 102 & 20 & 62 & 21 & & & & \\
\hline 6 & $1-5$ years & 54 & 18 & 31 & 7 & 7.442 & 6 & 16.81 & 12.591 \\
\hline & $6-10$ years & 17 & 4 & 11 & 2 & & & & \\
\hline & $>10$ years & 4 & 1 & 1 & 2 & & & & \\
\hline & Have you hear & about MBB & & & & & & & \\
\hline 7 & Yes & 116 & 36 & 62 & 17 & 10.004 & 2 & 9.21 & 5.991 \\
\hline & No & 64 & 7 & 43 & 15 & & & & \\
\hline
\end{tabular}

\section{DISCUSSION}

The finding of the study represents that majority $58.3 \%$ of the participants had an average knowledge and $23.9 \%$ had poor knowledge whereas 17.85 had good knowledge regarding menstrual blood banking. The overall mean percentage of knowledge score was $63.57 \%$ with the standard deviation of 8.43 .

A similar study result on effectiveness of structured teaching programme among nursing students on knowledge regarding menstrual blood stem cell banking reports that $92.7 \%$ nursing students had average knowledge regarding the concept in pretest while $88.5 \%$ of nursing students had good knowledge in the post-test. While on the contrary, mean post-test knowledge score was more than pretest knowledge score which was calculated by t-test $(t=19.197)$ at $\mathrm{p}<0.05$ level of significance. ${ }^{7}$

This study is a result of the researcher's zeal to cognise menstrual blood banking, which is prevalent, cutting-edge technology of collecting, 
preserving and storing of menstrual blood with the intention to utilise it for extracting stem cells which is quite like that of the umbilical cord blood sampling that's been impeding in majority of the medical institutes.

\section{CONCLUSION}

Present study was conducted to assess the knowledge of nursing students regarding menstrual blood banking. Outcome of the study shows that majority of the subjects had average knowledge. Considering these results, the investigator feels that there is lack of cognizance among future health professionals. The newer research evidences should be included into nursing curriculum in order to brush upon existing knowledge plus make them acquaint of updated techniques.

\section{REFERENCES}

1. Toyoda, M.et.al..Myogenic trans differentiation of menstrual blood-derived cells. ActaMyol. 2007.26(3):176-178

2. Julie G. Allickson et.al. Recent Studies Assessing the Proliferative Capability of a Novel Adult Stem Cell Identified in Menstrual Blood Open Stem Cell J.2011.3: 4-10.

3. Mrs. M. Marie Rosy (2017) Menstrual Blood Banking- A Review Int. J. Nur. Edu. And Research; 5(2): 213-217. DOI: 10.5958/24542660.2017.00046.1

4. Menstrual Fluid Banking. Available from: http://www.reelsabs.com/stem-cellbanking/menstrual-fluid-banking.html.

5. Banking Menstrual Stem Cells.(Monograph online) Available from: http://www.cryocell.com/menstrual/stem-cells.

6. Keng S I, Ahmad WANW, et.al. Association between nurse's knowledge and attitude toward stem cell application in medicine. The Malaysian Journal of nursing. 2016;7(3):3-9

7. Hans N, Kaur S. Effectiveness of structured teaching programme on knowledge regarding menstrual blood stem cells banking among nursing students. Int $J$ Repord Contracept Obstet Gynecol.2016 Sept;5(9):3137-40. Available at: www.ijrcog.org 